\title{
PATENT FORAMEN OVALE IN A COHORT OF YOUNG PATIENTS WITH CRYPTOGENIC ISCHEMIC STROKE
}

\author{
Marcus Tulius T. Silva1,2, Roíza Rodrigues², João Tress³, Rosaura Victer ${ }^{3}$, Francisco Chamiê ${ }^{4}$
}

\begin{abstract}
Objective: Although its role is a matter of debate, some studies described a higher prevalence of patent foramen ovale (PFO) and atrial septal aneurysm (ASA) in young stroke patients, with higher risk with PFO / ASA association (OR 4.96). The aim of this study was determine the prevalence of PFO and ASA in a cohort of cryptogenic ischemic stroke (IS) patients younger than 55 years and to follow-up after surg ical or percutaneous endovascular closure (PEC). Method: In 21 months we identified all patients less than 55 years old with IS who were admitted to our hospital. Cryptogenic IS was considered if there is not an identifiably cause to cerebral ischemia. Transesophageal echocardiography (TEE) was perf o rmed in all patients. After interatrial septal abnormalities diagnosis, percutaneous device closure was offered to all. Patients we refollowed monthly and keeped with oral AAS or Clopidogrel. Results: We identified 189 patients with IS and 32 were less than 55 years old (16.9\%). In 29 the IS was cryptogenic. TEE was perf o rmed in all patients and some form of interatrial septal abnormality was identified in 12 (12/29 - 41.3\%); 5 had a PFO and in 7 the re was PFO plus ASA. Ten patients were submitted to PEC and 2 were submitted to surgical closure. In mid-termfollow-up (28 months) no ischemic events occurred and 2 patients related disappearance of migraine symptoms. Conclusion: Our small series description is in accordance with other studies and suggests a possible relation between interatrial septal abnormalities and IS in a cohort of young patient.
\end{abstract}

KEY WORDS: ischemic stroke, patent foramen ovale, interatrial septal abnormalities.

\begin{abstract}
Forame oval patente em uma coorte de pacientes jovens com acidente vascular cerebral isquêmico
RESUMO - Objetivo: A associação das anormalidades do septo interatrial - forame oval patente (FOP) e aneurisma de septo interatrial (ASA) - com acidente vascular cerebral isquêmico (AVCI) ainda é questão de incerteza para muitos autores. No entanto, vários estudo mostram que em pacientes jovens tais anormalidades podem estar relacionadas à gênese de eventos isquêmicos. Nosso objetivo é descrever a prevalência do FOP e ASA em uma coorte de pacientes jovens ( $<55$ anos) com AVCl e acompanhar estes pacientes após fechamento cirúrgico ou por prótese endovascular. Método: Em 21 meses de estudo, identificamos todos os pacientes com menos de 55 anos de idade admitidos em nosso hospital por AVCl. Consideramos $\mathrm{AVCl}$ como criptogenético quando não havia uma causa provável para AVCl. Todos os pacientes foram submetidos ao ecocardiograma transesofágico. O fechamento por prótese endovascular foi o procedimento o fe recido àqueles com alguma anormalidade do septo interatrial. Os pacientes foram acompanhados mensalmente e submetidos a antiagregação plaquetária com AAS ou clopidogrel. Resultados: Foram admitidos 32 pacientes jovens com AVCl. Após ampla investigação, 29 receberam o diagnóstico de AVCl criptogênico. Destes, 12 (12/29 - 41,3\%) apresentaram alguma anormalidade do septo interatrial; sendo que em 7 havia a associação de FOP e ASA. Dez pacientes foram submetidos a fechamento endovascular percutâneo e 2 foram submetidos a fechamento cirúrgico. Até o momento, nenhum paciente relatou recorrência do evento isquêmico e 2 pacientes relataram melhora das crises de enxaqueca (14 meses de seguimento). Conclusão: Nossa pequena série de casos está de acordo com outros estudos e sugere uma possível relação entre anormalidades do septo interatrial e AVCl em pacientes jovens. Maiores estudos são necessários para comprovar esta associação e para definir a melhor conduta terapêutica.
\end{abstract}

PALAVRAS-CHAVE: acidente vascular cerebral isquêmico, forame oval patente.

Interatrial septal abnormalities - patent foramen ovale (PFO) and atrial septal aneurysm (ASA) - have been postulated as a possible cause for emboli among young ischemic stroke patients'. Although its role is a matter of debate and earlier studies have suggested that PFO is an incidental finding (no representing a risk factor for ischemic stroke), case studies and series have described a higher prevalence of PFO and/or ASA in young stroke patients than in the controls ${ }^{2}$. PFO was detected in more than $50 \%$ in one

\footnotetext{
'Departamento de Neurologia, Universidade Federal Fluminense, Niterói RJ, Brasil (UFF); ${ }^{2}$ S e rviço de Neurologia Hospital de Clínicas Niterói (HCN); ${ }^{3}$ Serviço de Ecocardiografia UFF e HCN; ${ }^{4}$ Serviço de Cardiologia Intervencionista HCN.
}

Received 12 July 2004, received in final form 24 November 2004. Accepted 22 January 2005. 
study, whereas its prevalence in the general population is at least $25 \%{ }^{3,4}$. In a recent meta-analysis, Overell et al examined all published case-control studies, and concluded that PFO and ASA were significantly associated with ischemic stroke in patients younger than 55 years, with higher risk among patients with PFO plus ASA (OR 1.83 for PFO [95\%, Cl 1.25 to 2.66], OR 2.35 for ASA [95\%, Cl 1.46 to 3.77] and OR 4.96 for PFO plus ASA [95\%, Cl 2.37 to 10.39$])^{5}$.

The aim of this prospective study was to determine the prevalence of interatrial septal abnormalities in a cohort of cryptogenic ischemic stroke patients younger than 55 years in a general hospital. We also aimed follow-up the cohort after surgical or percutaneous endovascular closure, presenting our partial results about recurrence of ischemic events.

\section{METHOD}

From March 2001 to December 2002 we identified all patients less than 55 years old with ischemic stroke who were admitted to our hospital, the largest in a city of almost 450000 inhabitants. All patients were submitted to either brain CT and angioCT or brain MRI and angioMRI. The patients were also submitted to carotid and vertebral Doppler scan, antinuclear factor and antiDNA antibodies determination, erythrocyte sedimentation rate, VDRL and HIV antibodies search, Protein C, S, activated-protein $\mathrm{C}$, antithrombin III and Leiden V factor studies, and homocystein, antiphospholipid and antic a rdiolipin antibodies determinations. Diagnosis of stroke was based on a focal neurological deficit and the corresponding findings on $\mathrm{CT}$ and MRI, and cryptogenic ischemic stroke was considered if there was not an identificable cause to cerebral ischemia. The exclusion crite- ria were: lacunar infarcts, transient ischemic attacks, a mau rosis fugax, cocaine or amphetamin use preceding the ischemia, sickle cell anemia, significant intracranial and extracranial vascular disease (including dissections), diabetes, arterial hypertension, current smoking, other emboligenic source than PFO or ASA and suspect cases of migranous infarct. We also excluded patients without acute CT or MRI abnormalities compatible with ischemic stroke. Transesophageal echocardiography (TEE) was performed in all patients. A mixed of cefalotin and saline $0.9 \%$ was injected in a peripheral venous during TEE to assess interatrial septum entirety. PFO was defined as the presence of right-to-left shunt at interatrial level. Diagnosis requi red appearance of at least one microbubble of contrast in the left atrium within four cardiac cycles of opacification of the right atrium. PFO was present whenever Septum Primum was actually detached from the superior rim of the Oval Fossa, allowing opening of the tunnel in the left atrium, this being the sole orifice in interatrial septum. ASA was defined by base width of $1.5 \mathrm{~cm}$ or greater, with at least $1.1 \mathrm{~cm}$ excursion into either the left or the right atrium, or sum of the total excursion into the left or right atrium of $1.1 \mathrm{~cm}$ or greater. After diagnosis, percutaneous device closure (PDC) was offered to all patients with either the Amplatzer PFO Occluder or the Helex Septal Occluder. After percutaneous closure, all patients received clopidogrel (75 $\mathrm{mg} /$ day for $1 \mathrm{month}$ ) and aspirin (100-300 mg/day for 6 months) and were examined each 2 months after discharge for at least 1 year. An informed consentiment was signated by all patient enrolled in study.

\section{RESULTS}

From March 2001 to December 2002, 189 patients with defined ischemic stroke were admitted

Table. Demographic data and characteristics of patients.

\begin{tabular}{ccclcc}
\hline Patient & Age & Sex & Clinical features & TEE* & Migraine history \\
\hline 1 & 19 & F & Left facial and arm paresthesia & PFO + ASA & No \\
2 & 51 & M & Homonymous hemianopia & PFO + ASA & No \\
3 & 54 & M & Left hemiparesis & PFO & No \\
4 & 22 & F & Left hemiparesis & PFO & Yes \\
5 & 36 & F & Right hemiparesis & PSA & Yes \\
6 & 50 & F & Right hemiparesthesia & ASA & Yes \\
7 & 38 & M & Motor aphasia and hemiparesis & PFO & No \\
8 & 45 & F & Right leg paresthesia & PFO & Yes \\
9 & 53 & M & Right hemiparesis & No \\
10 & 23 & M & Left hemiparesis, dysarthria & PFO + ASA & No \\
11 & 52 & M & Right facial and brachial paresis & PFO + ASA & No \\
12 & 51 & F & Right hemiparesis & PFO & Yes \\
\hline * TEE, transesophagic echocardiography findings; PFO, patent foramen ovale; ASA, atrial septal aneurysm; F, Female; M, Male.
\end{tabular}


to our hospital. Thirty-two (16.9\%) were less than 55 years old. In two patients the final diagnosis was septic embolism by endocarditis and in one we o bs e rvedan ipsilateral symptomatic carotid stenosis of $85 \%$. In 29 the cause of ischemia could not be determined (cryptogenic ischemic stroke). TEE was performed in all patients and some form of interatrial septal abnormality was identified in 12 $(12 / 29-41.3 \%)$. Five had a PFO and seven had PFO plus ASA (demographic data in Table). Two patients (5 and 8) presented with previous ischemic events (TIA and stroke, respectively) and 5 had a previous history of classic migraine. Ten patients were submitted to PEC, and surgical closure was perfo rmed in two because of financial difficulties (patient 1 and 5). In mid-term follow-up (28 months) no ischemic events occurred and two patients spontaneously related disappearance of migraine symptoms (patient 6 and 8).

\section{DISCUSSION}

Our small series is in accordance of other studies that demonstrate a higher prevalence of interatrial septal abnormalities in young stroke patients than due $(41.3 \%)$, inasmuch as PFO or ASA prevalence in a healthy population is around $25 \% 4$.

Although previous studies have shown an association between PFO and stroke, the ideal secondary ischemic stroke prevention for such patients is not known because there is not a randomized trial to date. Yet, even in young patients cerebral infarction had considerable impact in mortality, re ccurence and employment status ${ }^{6}$. So, measures to prevent recurrence were of utmost importance. Currently, surgical or percutaneous device closure and medical therapy with long life anticoagulation or antiplatelet agents are the major choices to prevent recurrent strokes or $\mathrm{TIA}^{7}$. Maybe the surgical or endovascular closure could be the best option in very young patients if we consider the risks of a long life anticoagulation or antiplatelet therapy. Indeed, the rate of recurrent cerebrovascular events during 2 to 3 years of antithrombotic treatment varies from $3.4 \%$ to $9.2 \%$, but if there is ASA in addition to the PFO this risk could increase to $9.0 \%$ for stroke and $22 \%$ for TIA and/or stroke in 2 years ${ }^{7-10}$. Recently, some reports have identified additional risk factors that increase the probability of recurrence of stroke among PFO patients, like a previous personal history of stroke or TIA, atrial septal hypermotibility, ASA combined with PFO, and the size of PFO7, ${ }^{11-13}$.
Nowadays, some studies have reported an increased prevalence of PFO in patients with migraine with aura, and closure of PFO was associated with complete disappearance of migraine attacks in some patients ${ }^{14,15}$. Although this is not be the aim of this paper, in our small series, two patients (mother and daughter, 6 and 4 respectively) reported disappearance of aura and reduction of migraine attacks along 28 months of follow-up.

In conclusion, we showed that $41.3 \%$ of young patients with cryptogenic ischemic stroke had PFO or PFO plus ASA. Our small series description is in accordance with other studies and points to a possible relation between interatrial septal abnormalities and ischemic stroke in a cohort of young patient. This relation needs to be confirmed by a large study, as well as in older patients with ischemic stroke and no identificable risk factors.

\section{REFERENCES}

1. Ranoux D, Cohen A, Cabanes L, Amarenco P, Bousser MG, Mas JL. Patent foramen ovale: is stroke due to paradoxical embolism? Stroke 1993;24: 31-34.

2. Jones HR. Jr., Caplan LR, Come PC, Swinton NW Jr., Breslin DJ. Cerebral emboli of paradoxical origin. Ann Neurol 1983;13:314-319.

3. Lechat P, Mas JL, Lascault G, et al. Prevalence of patent foramen ovale in patients with stroke. N Engl J Med 1988;318:1148-1152.

4. Hagen PT, Scholz DG, Edwards WD. Incidence and size of patent foramen ovale during the first 10 decades of life: an autopsy study of 965 normal hearts. Mayo Clin Proc 1984;59:17-20.

5. Overell JR, Bone I, Lees KR. Interatrial septal abnormalities and stroke: a meta-analysis of case-control studies. Neurology 2000;55:1172-1179.

6. Naess H, Nyland HI, Thomassen L, Aarseth J, Myhr KM. Long-term outcome of cerebral infarction in young adults. Acta Neurol Scand 2004;110:107-112.

7. Nedeltchev K, Arnold M, Wahl A, et al. Outcome of patients with cryptogenic stroke and patent foramen ovale. J Neurol Neurosurg Psychiatry 2002;72:347-350.

8. Bogousslavsky J, Garazi S, Jeanrenaud X, Aebischer N, Van Melle G. Stroke recurrence in patients with patent foramen ovale: the Lausanne Study. Lausanne Stroke with Paradoxal Embolism Study Group. Neurology 1996;46:1301-1305.

9. Castro S, Cartoni D, Fiorelli M, et al. Morphological and functional characteristics of patent foramen ovale and their embolic implications. Stroke 2000;31:2407-2413.

10. Mas JL, Zuber M. Recurrent cerebrovascular events in patients with patent foramen ovale, atrial septal aneurysm, or both and cryptogenic stroke or transient ischemic attack. French Study Group on Patent Foramen Ovale and Atrial Septal Aneurysm. Am Heart J 1995;130:1083-1085.

11. Comess KA, DeRook FA, Beach KW, Lytle NJ, Golby AJ, Albers GW. Transesophageal echocardiography and carotid ultrasound in patients with cerebral ischemia: prevalence of findings and recurrent stroke risk. J Am Coll Cardiol 1994;23:1598-1603.

12. Cabanes L, Mas JL, Cohen A, et al. Atrial septal aneurysm and patent foramen ovale as risk factors for cryptogenic stroke in patients less than 55 years of age: a study using transesophageal echocardiography. Stroke 1993;24:1865-1873.

13. Schuchlenz HW, Weihs W, Horner S, Quehenberger F. The association between the diameter of a patent foramen ovale and the risk of embolic cerebrovascular events. Am J Med 2000;109:456-462.

14. Del Sette M, Angeli S, Leandri M, et al. Migraine with aura and rightto-left shunt on transcranial Doppler: a case-control study. Cerebrovasc Dis 1998;8:327-330.

15. Sztajzel R, Genoud D, Roth S, Mermillod B, Le Floch-Rohr J. Patent foramen ovale, a possible cause of symptomatic migraine: a study of 74 patients with acute ischemic stroke. Headache 2003;43:305-306. 